Uludag Univ. J. Fac. Vet. Med.

36 (2017), 1,2: 33-35

\title{
Bir Köpekte Tek Taraflı Luteoma Olgusu
}

\author{
Geliş Tarihi:17.08.2017 \\ Düzeltme Tarihi:12.09.2017, Kabul Tarihi:15.12.2017
}

\author{
Rahşan YILMAZ1， M. Özgür ÖZYİĞİT²， Ahmet AKKOÇ²
}

\begin{abstract}
Özet: Bu olguda, Terrier 1rkı, dişi, 13 yaşlı köpeğin sol ovaryumunda nadir olarak şekillenen luteomanın makroskobik ve mikroskobik özellikleri tanımlanmıştır. Klinik olarak bir haftadan beri süren iştahsızlık ve kusma bulguları ile Veteriner Fakültesi Kliniklerine getirilen hayvanın ultrasonografik muayenesinde batın içerisinde $13 \times 11 \mathrm{~cm}$ boyutlarında tamamen hipoekoik ve yer yer normal dokulara göre farklı ekojenitede homojen yapı gösteren kitleye rastlandı. Yapılan operasyonda tümöral kitle ile beraber ovaryum ve uterus, makroskobik ve histopatolojik inceleme için patoloji laboratuvarına gönderildi. Makroskobik muayenesinde kitlenin 13x 11x $8 \mathrm{~cm}$ boyutlarında, orta sert kıvamlı, kesit yüzü krem renkte ve yer yer kanama alanları içerdiği görüldü. Histopatolojik incelemede, sol ovaryumun tamamen tümöral doku ile kaplanmış olduğu ve normal ovaryum yapısına ait hiçbir histolojik doku içermediği dikkati çekti. Tümörün hücre sınırları belirgin, eozinofilik sitoplazmalı, sitop-lazmasında yağ vakuolleri olan, açık veziküler çekirdekli, belirgin çekirdekçiğe sahip, yer yer ince bağ doku kordonları ile birbirinden ayrılan poligonal hücre kümelerinden oluştuğu dikkati çekti. Tümöral dokuda yer yer mitotik figürlere rastlandı. Bazı alanlarda nekroz ve kanama görüldü. Bu olayda, makroskobik ve histopatolojik inceleme sonucunda sol ovaryumda nadir görülen luteoma olgusu tanımlanmıştır.
\end{abstract}

Anahtar Kelimeler: Köpek, ovarium, luteoma.

\section{Unilateral Luteoma in the Ovary of a Dog}

\begin{abstract}
In this case, ovarial luteoma in the left ovary in a 13-year-old Terrier was defined both macroscopically and microscopically. The dog had a history of vomiting and anorexia for a week. In palpation, sensitivity observed on the left abdominal region of the animal. Ultrasonographically a hypoechoic, round mass with homogeny architecture, $13 \times 11 \mathrm{~cm}$ in size, located in the left abdominal region was found. The both ovary with tumoural mass and uterus were taken by operation and masses were referred to pathology laboratory for histopathological examination. Macroscopically, the left ovarial mass, $13 \mathrm{x} 11 \mathrm{x} 8$ $\mathrm{cm}$ in size, was moderately firm, round, multilobulated and encapsulated and the cut surface had a yellowish appearance. There were focal areas of hemorrhages and necrosis. In microscopical examination, neoplastic cells were arranged in irregular shaped solid sheet. The nuclei were small, round to oval and had coarsely stippled chromatin. The amount of cytoplasm varied from scant to moderate and was faintly eosinophilic and finely granular or vacuolated. Luteinized cells had prominent eosinophilic cytoplasm and pale staining nuclei. Few mitotic figures were seen in the sections. The left ovary was completely invaded by neoplastic cells and the normal histological architecture was not observed. However in the right ovary and uterus was not found pathological lesion by histological examination. In the light of the macroscopical and microscopical findings the tumour was found compatible with ovarial luteo-ma.
\end{abstract}

Key Words: Dog, ovarium, luteoma.

1 Yrd. Doç. Dr.Harran Ünivetsitesi Veteriner Fakültesi Patoloji ABD 63200 Eyyübiye Kampüsü, Şanlıurfa.

2 Doç. Dr. Uludağ Üniversitesi Veteriner Fakültesi Patoloji ABD 16059 Görkle Kampüsü, Bursa.

ozyigit@uludag.edu.tr 


\section{Giriş}

Ovaryum tümörleri, inek, kısrak, domuz, köpek ve kedi gibi birçok evcil hayvanlar ile laboratuvar hayvanlarında tanımlanmıştır ${ }^{7,9}$. Köpeklerde genital tümörler daha çok vulva ve vaginada gözlenirken primer ovaryum tümörleri daha nadirdir ${ }^{3,6}$. Hayvanlarda ovaryum tümörleri, epitelyal tümörler, germ hücre tümörleri ve seks-kord stromal tümörleri olmak üzere 3 gruba ayrılır ${ }^{2,5,7,11}$. Luteoma köken olarak seks-kord stromal tümörler içerisinde yer alır ${ }^{5,11}$. Luteoma, korpus luteuma benzeyen lüteinize hücrelerden oluşmus sarı kahve renkte, soliter yapıda oldukça büyük boyutlara ulaşabilen tümörler için kullanılan bir terimdir ${ }^{4,8}$. Luteoma özellikle sol ovaryumda şekillenir ve doğumdan sonra geri$\operatorname{ler}^{7,8}$. Köpeklerde ovaryum tümörleri kısırlaştırılmış çoğunlukla orta ve ileri yaşlı hayvanlarda gözlenir ${ }^{6}$. Bu olayda kısırlaştırılmamış, terrier 1rkı, 13 yaşl1, dişi bir köpekte sol ovaryumda tek taraflı luteoma olgusu tanımlanmıştır.

\section{Olgunun Tanımı}

Hayvan bir haftadan beri süren iştahsızlık ve kusma bulguları ile Veteriner Fakültesi Kliniklerine getirildi. Klinik muayenede, palpasyonda hayvanın sol açlık çukurluğu hizasında hassasiyet gözlendi. Yapılan ultrasonografik muayenede batın içerisinde $13 \times 11 \mathrm{~cm}$ boyutlarinda tamamen hipoekoik yer yer normal dokulara göre farklı ekojenitede homojen bir kitleye rastland1. Operasyon sonrası tümöral kitle ile beraber ovaryum ve uterus makroskobik ve histopatolojik inceleme için patoloji laboratuvarına gönderildi. Makroskobik muayenede kitlenin 13x 11x $8 \mathrm{~cm}$ boyutlarında (Resim1), orta sert kıvamlı, kesit yüzü krem renkte ve yer yer kanama alanları içerdiği görüldü (Resim 2). Histopatolojik incelemede, tümörün hücre sınırları belirgin, eozinofilik sitoplazmalı, sitoplazmasında yağ vakuolleri olan, açık veziküler çekirdekli, belirgin çekirdekçiğe sahip, yer yer ince bağ doku kordonları ile birbirinden ayrilan poligonal hücrelerden oluştuğu gözlendi (Resim 3). Tümöral doku içerisinde da yer yer mittik figür görüldü. Kesit alanı içerisinde nekrotik ve kanamalı alanlara rastland. Sol ovaryumun tamamen tümöral doku ile kaplanmıș olduğu ve normal ovaryum yapısına ait hiçbir histolojik doku içermediği dikkati çekti. Bu olayda, makroskobik ve histopatolojik inceleme sonucunda sol ovaryumda nadir görülen luteoma tanısı konuldu.

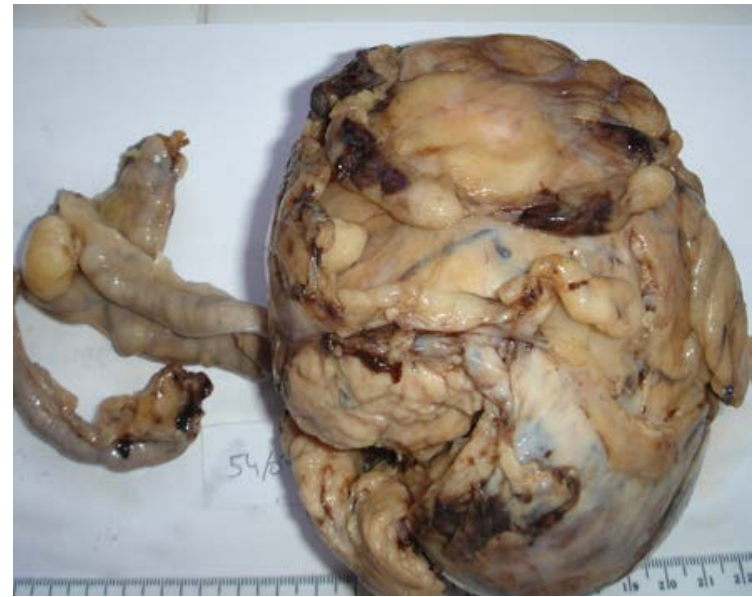

Resim 1: Sol ovaryumda gözlenen tümöral kitle (luteoma)

Figure 1: Tumoral wass observed on left ovarium

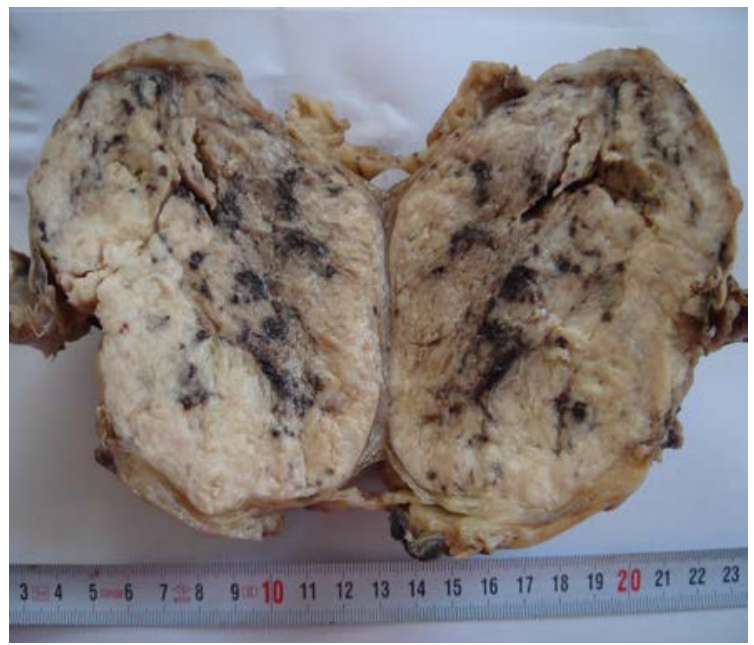

Resim 2: Kesit yüzünde yer yer kanamall solid alanlar

Figure 2: Heamorhagic areas at solide cut section

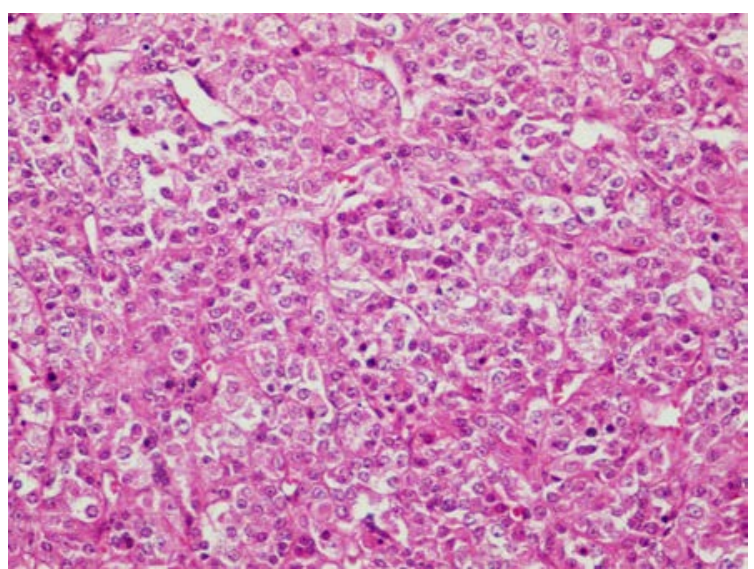

Resim 3: İnce bağ doku ile ayrılmış açık veziküler çekirdekli poligonal hücreler X400, H.E.

Figure 3: Polyganal tumoral cells separated by connective tissue. 


\section{Tartışma}

Köpeklerde genital tümörler daha çok vulva ve vajinada gözlenirken primer ovaryum tümörleri nadirdir ${ }^{3,6}$. ovaryum tümörlerin nedenleri tam olarak bilinmemektedir ${ }^{6}$. Nadir olan bu tümörlerden En sık görülen ovaryum tümörleri arasında papillar adenoma, papillar adenokarsinoma ve granuloza hücre tümörleri yer almaktadır. Kistadenoma, medullar karsinoma, disgerminoma, teratoma, tekoma ve luteoma daha nadir görülen ovaryum tümörlerdir ${ }^{3}$. Luteoma ovaryumun iyi huylu bir tümörüdür. Genellikle tek tarafl1, yuvarlak, beyazdan turuncu renge kadar değișen renkte, düzgün yüzeyli solid bir yap1 göstermektedir ${ }^{6,8,9}$. Histolojik olarak granuloza hücrelerinden köken alırlar ve luteal hücrelerden meydana gelirler. Oldukça nadir gözlenen tümör sinırlı olarak büyür ve metastaz yap$\mathrm{maz}^{6,8}$. Tümöre bağlı olarak hayvanda orta derecede virilizasyon (erkeksi davranışlar) görülebi$\operatorname{lir}^{2,8}$. Luteoma genellikle gebelikle ilişkilidir ve doğumdan sonra geriler? ${ }^{7}$. Gebelik luteoması gebelik sırasında bir tümör gibi davranabilen ovaryum genişlemesi ile karakterize nonneoplastik bir lezyondur ve gebelik sirasında koriyonik gonodotropin etkisi altında lüteinleşen stromal hücrelerin normal ovaryum parankimi ile yer değiştirmesinden veya yüksek HCG düzeyine yanıt olarak ovaryumun stromasından ya da internal teka hücelerinden gelişiri,10. Bu olayda hayvanın gebe kaldığına ve doğum yaptığına dair herhangi bir klinik ve makroskobik bulguya rastlanamadı. Bu durum gelişen luetomanın gebelikle ilişkili değil primer olarak ovaryumdan köken alabileceğini göstermektedir. Ayrıca ovaryum tümörleri daha çok kısırlaştırılmış hayvanlarda görülür ${ }^{5,6}$. Bu olayda hayvanda her iki ovaryum ile birlikte uterus sağlamdı. Luteomalar daha çok fibroma ile karışabilir, ayrımı tümör hücrelerinin sitoplazması içerisindeki lipid materyalinin gösterilmesi ile yapılmaktadır ${ }^{9}$. Luteoma bildirilen köpeklerde belirli bir 1rk predizpozisyonu yoktur ${ }^{4}$.

\section{Kaynaklar}

1. Banrjee, A., Tahmasebi, F., Myola, E., Yoong, W., 2006. Luteoma of pregnancy. J Obstet Gynaecol. 6, 572-574.

2. Benson, C.R., 1977. Hanbook of obstetrics and gynecology, 8th. Los Altos, California.

3. Jergens, A.E., Shaw, D.P., 1987. Tumors of the canine ovary. Comp cont educ pract. 5, 489-495

4. MacLachlan, N.J., Kennedy, P.C., 1990. Tumors of the Genital Systems. In. Meuton D.J (Ed), Tumors in Domestic Animals. 4th ed., Iowa state Press, pp. 547-573.

5. McEntee M.C., 2002. Reproductive oncology. Clin Tech Small Anim Pract. 3, 133-149.

6. Moris, J., Dobson, J., 2001. Small Animal Oncology, 1th Ed., Iowa State University Pres, Iowa pp.166-167.

7. Nagarajan, P., Venkatesan, R., Kumar, M.J., Majumdar, S.S., 2005. Granulosa theca cell tumor with luteoma in the ovary of a bonnet monkey (Macaca Radiata). J Med Primatol. 34, 219223.

8. Rosai J., 2004. Rosai and Ackerman's Surgical Pathology, 5th. ed., Mosby, pp. 1655-1656.

9. Schlafer, D.H., Foster, R.A., 2016 Female Genital System. In. Jubb, K.V.F., Kennedy, P.C., Palmer, N. (Eds.), Pathology of Domestic Animals, Elsevier. St Lois Missouri, pp 359-464.

10. Sorianella, E.M., Fernandez, P. N., Catalano, L.A., Mongiat, G.M., Somoza, C., Libertun, T., Lux-Lantos, V. A., 2005. Differential gonadotropin releasing hormone $(\mathrm{GnRH})$ expression autoregulation and effects in two models of rat luteinized ovarian cell. Life Sci. 77, 2141-2155.

11. Yamini, B., Vandenbrink, P.L., Refsal, K.R., 1997. Ovarian steroid cell tumor resembling luteoma associated with hyperadrenocorticism (cushing's disease) in a dog. Vet Pathol. 34, 5760. 
